Marquette University

e-Publications@Marquette

Biological Sciences Faculty Research and

Publications

Biological Sciences, Department of

$2-2016$

\title{
mcrA Gene Abundance Correlates with Hydrogenotrophic Methane Production Rates in Full-scale Anaerobic Waste Treatment Systems
}

\author{
R. L. Morris \\ Marquette University \\ Vaibhav Panjabrao Tale \\ Marquette University \\ P. P. Mathai \\ Marquette University \\ Daniel Zitomer \\ Marquette University, daniel.zitomer@marquette.edu \\ James Maki \\ Marquette University, james.maki@marquette.edu
}

Follow this and additional works at: https://epublications.marquette.edu/bio_fac

Part of the Biology Commons

\section{Recommended Citation}

Morris, R. L.; Tale, Vaibhav Panjabrao; Mathai, P. P.; Zitomer, Daniel; and Maki, James, "mcrA Gene Abundance Correlates with Hydrogenotrophic Methane Production Rates in Full-scale Anaerobic Waste Treatment Systems" (2016). Biological Sciences Faculty Research and Publications. 506.

https://epublications.marquette.edu/bio_fac/506 
Marquette University

e-Publications@Marquette

\section{Biological Sciences Faculty Research and Publications/College of Arts and Sciences}

This paper is NOT THE PUBLISHED VERSION.

Access the published version at the link in the citation below.

Letters in Applied Microbiology, Vol. 62, No. 2 (February 2016): 111-118. DOI. This article is (C) The Society for Applied Microbiology and permission has been granted for this version to appear in $\underline{\text { e- }}$ Publications@Marquette. The Society for Applied Microbiology does not grant permission for this article to be further copied/distributed or hosted elsewhere without the express permission from The Society for Applied Microbiology.

\section{Mcra Gene Abundance Correlates with Hydrogenotrophic Methane Production Rates} in Full-Scale Anaerobic Waste Treatment

\section{Systems}

R.L. Morris

Department of Biological Sciences, Marquette University, Milwaukee, WI

V.P. Tale

Department of Civil, Construction and Environmental Engineering, Water Quality Center, Marquette University, Milwaukee, WI

P.P. Mathai

Department of Biological Sciences, Marquette University, Milwaukee, WI

D.H. Zitomer 
Department of Civil, Construction and Environmental Engineering, Water Quality Center, Marquette University, Milwaukee, WI

\section{J.S. Maki}

Department of Biological Sciences, Marquette University, Milwaukee, WI

\section{Abstract}

Anaerobic treatment is a sustainable and economical technology for waste stabilization and production of methane as a renewable energy. However, the process is under-utilized due to operational challenges. Organic overload or toxicants can stress the microbial community that performs waste degradation, resulting in system failure. In addition, not all methanogenic microbial communities are equally capable of consistent, maximum biogas production. Opinion varies as to which parameters should be used to monitor the fitness of digester biomass. No standard molecular tools are currently in use to monitor and compare full-scale operations. It was hypothesized that determining the number of gene copies of $m c r A$, a methanogen-specific gene, would positively correlate with specific methanogenic activity (SMA) rates from biomass samples from six full-scale anaerobic digester systems. Positive correlations were observed between mcrA gene copy numbers and methane production rates against $\mathrm{H}_{2}: \mathrm{CO}_{2}$ and propionate $\left(R^{2}=0.67-0 \cdot 70, P<0.05\right)$ but not acetate $\left(R^{2}=0.49, P>0.05\right)$. Results from this study indicate that $m c r A$ gene targeted qPCR can be used as an alternate tool to monitor and compare certain methanogen communities in anaerobic digesters.

\section{Significance and Impact of the Study}

Using quantitative PCR (qPCR), we demonstrate that the abundance of $m c r A$, a gene specific to methane producing archaea, correlated with specific methanogenic activity (SMA) measurements when $\mathrm{H}_{2}$ and $\mathrm{CO}_{2}$, or propionate were provided as substrates. However, mcrA abundance did not correlate with SMA with acetate. SMA values are often used as a fitness indicator of anaerobic biomass. Results from qPCR can be obtained within a day while SMA analysis requires days to weeks to complete. Therefore, qPCR for mcrA abundance is a sensitive and fast method to compare and monitor the fitness of certain anaerobic biomass. As a monitoring tool, qPCR of $m c r A$ will help anaerobic digester operators optimize treatment and encourage more widespread use of this valuable technology.

\section{Introduction}

Anaerobic waste treatment is often a sustainable, economical process in which the degradation of organic compounds in industrial and municipal wastes result in the biological production of a renewable energy source: methane. However, anaerobic bioprocesses may be under-utilized due to operational challenges, such as difficult start-up and transient periods of poor operation

(Speece 1996). Prudent use of monitoring and control has been used or suggested to help prevent failure or encourage faster start-up and recovery of stressed digesters (Castellano et al. 2007; SchauerGimenez et al. 2010). Activity testing, such as specific methanogenic activity (SMA) assays, has been used to determine maximum methane production rates of anaerobic biomass given specific substrates (Coates et al. 1996, 2005). Unfortunately, days to weeks are typically required to obtain activity results, limiting applicability for real-time optimization. 
Digester microbial communities are complex, with multiple trophic levels in which different groups of organisms carry out waste degradation in a series of steps (Schink 1997; Fernandez et al. 1999; White 2000; Leclerc et al. 2004; Liu and Whitman 2008; Rivière et al. 2009). The methanogens are especially important as the last link in the food chain, performing the final step in the degradation of organic waste to methane (McCarty and Smith 1986). Additionally, their function is closely tied to that of the syntrophic fatty-acid degrading bacteria that metabolize these compounds and depend upon hydrogen removal by methanogens (Schink 1997; Conrad and Klose 1999). Furthermore, methanogenesis is often considered to be the rate-limiting step in anaerobic treatment of many wastes (Liu and Whitman 2008). Therefore, methanogens are critical for digester stability. Monitoring this specific group of organisms may provide an important link between digester function and microbial community structure.

Methanogens possess an operon that encodes the methyl coenzyme $M$ reductase (MCR). The presence and transcription of the gene that encodes the alpha subunit of MCR ( $m c r A$ ) has been used to detect methanogen presence and activity in the environment (Springer et al. 1995; Luton et al. 2002; Juottonen et al. 2008; Steinberg and Regan 2009; Kampmann et al. 2012; Zeleke et al. 2013; Bocher et al. 2015). Previously, we showed that mcrA gene copy numbers, but not transcript numbers, positively correlated with SMA values in laboratory methanogenic enrichments (Morris et al. 2014). An advantage of qPCR of mcrA over SMA analysis is that relevant data can be obtained in a much shorter period of time.

This study was performed to test the hypothesis that the mcrA gene copy numbers positively correlate to SMA values determined for industrial and municipal anaerobic biomass. Herein, we report the comparison of mcrA gene abundance to SMA values from biomass collected from six full-scale anaerobic treatment plants.

\section{Results and discussion}

Methanogen community fingerprint with denaturing gradient gel electrophoresis (DGGE)

Biomass from the six different full-scale digesters (Table 1) was examined for the presence and structure of the methanogen community by fingerprinting using the mcrA gene and DGGE. The results revealed a unique methanogen community within each full-scale digester (Fig. 1a). A dendogram constructed from the densitometric data from the gel confirmed that the communities were different even when the substrates were similar (Fig. 1b). For example, the biomass from both MSS and MBR, which were municipal anaerobic digesters, appeared in different clades (Fig. 1b).

Table 1. Description of anaerobic waste treatment systems and operating conditions. Results provided by operators in response to a questionnaire

\begin{tabular}{|l|l|l|l|l|l|l|}
\hline Digester & Substrate & $\begin{array}{l}\text { Operating } \\
\text { temperature } \\
\left({ }^{\circ} \mathrm{C}\right)\end{array}$ & $\mathbf{p H}$ & Biogas production & Organic loading rate & $\begin{array}{l}\text { Hydraulic } \\
\text { retention } \\
\text { time }\end{array}$ \\
\hline $\mathrm{CB}$ & $\begin{array}{l}\text { Brewery } \\
\text { waste }\end{array}$ & $26 \cdot 7-29 \cdot 4$ & $\begin{array}{l}6 \cdot 5- \\
8 \cdot 0\end{array}$ & $\begin{array}{l}351 \cdot 3 \mathrm{I} \mathrm{kg}^{-1} \mathrm{COD} \\
\text { removed }\end{array}$ & NP & $4 \cdot 4 \mathrm{~h}$ \\
\hline $\mathrm{KI}$ & $\begin{array}{l}\text { Milk-derived } \\
\text { food additive } \\
\text { waste }\end{array}$ & $35 \cdot 6-36 \cdot 7$ & $7 \cdot 0$ & $19369 \mathrm{SCM} \mathrm{day}^{-1}$ & $\mathrm{NP}$ & $7-10$ days \\
\hline
\end{tabular}




\begin{tabular}{|l|l|l|l|l|l|l|}
\hline CF & $\begin{array}{l}\text { Dairy cow } \\
\text { manure } \\
\text { waste }\end{array}$ & NP & NP & NP & NP & NP \\
\hline JBS & $\begin{array}{l}\text { Beef } \\
\text { slaughter } \\
\text { waste }\end{array}$ & $36 \cdot 1$ & $7 \cdot 0$ & $130 \mathrm{SCM} \mathrm{day}^{-1}$ & $1.6 \mathrm{~kg} \mathrm{COD} \mathrm{m}^{-3}$ day $^{-1}$ & $3-4$ days \\
\hline MBR & $\begin{array}{l}\text { Municipal } \\
\text { waste }\end{array}$ & $36 \cdot 2$ & $7 \cdot 1$ & $6884 \mathrm{SCM} \mathrm{day}^{-1}$ & $0.80 \mathrm{~kg} \mathrm{VS} \mathrm{m}^{-3}$ day $^{-1}$ & 53 days \\
\hline MSS & $\begin{array}{l}\text { Municipal } \\
\text { waste }\end{array}$ & $35 \cdot 8$ & $7 \cdot 2$ & $17238 \mathrm{SCM} \mathrm{day}^{-1}$ & $0.32 \mathrm{~kg} \mathrm{VS} \mathrm{m}^{-3}$ day $^{-1}$ & 47 days \\
\hline
\end{tabular}

$\mathrm{NP}=$ not provided by operator; $\mathrm{COD}=$ chemical oxygen demand; $\mathrm{SCM}=$ standard cubic meter; $\mathrm{VS}$ = volatile solids.
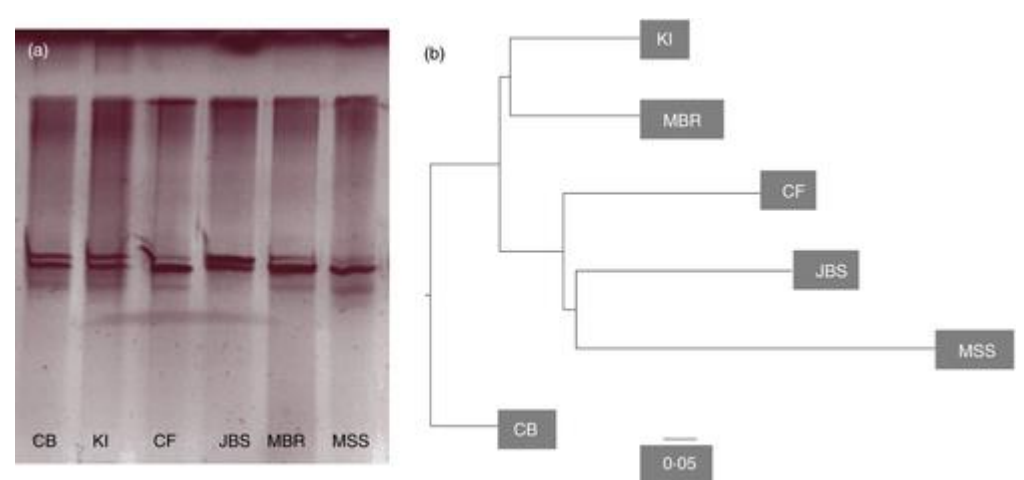

Figure 1. Community fingerprint analysis using denaturing gradient gel electrophoresis (DGGE) of $m c r A$ from fullscale industrial and municipal anaerobic digesters. (a) DGGE fingerprint of $m c r A$ genes present in full-scale biomass samples. Lanes are labelled with sample names. See Table 1 for more information regarding each sample. (b) Dendrogram showing relationships between the methanogen communities in the full-scale digesters based on optical density data from the DGGE gel.

\section{Quantitative PCR (qPCR) of $m c r A$}

All qPCR analyses were performed in one run, and critical parameters were as follows: slope -3.662 , yintercept $5 \cdot 465$, correlation coefficient $0 \cdot 933$, efficiency $87 \cdot 5 \%, C_{t}$ of the no-template control $26 \cdot 45$. Total mcrA copy number per ng DNA (Fig. 2a) and per g of wet pellet biomass (Fig. 2b) was calculated from qPCR results. When the results were normalized to $g$ of pellet as opposed to ng of DNA the digester with the highest mcrA copy number switched from biomass JBS to biomass CB (Fig. 2). This normalization with pellet biomass was performed because it was thought to be more similar to the volatile suspended solids (VSS) measurement used to normalize the SMA values. 

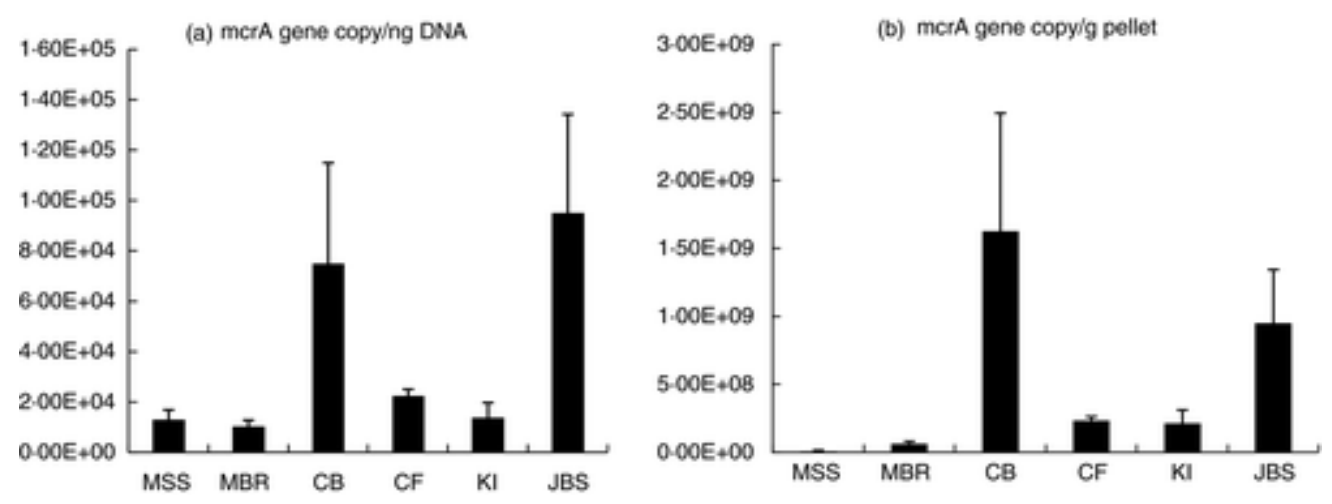

Figure 2. Results of qPCR using industrial and municipal anaerobic digester biomass. Each bar represents results from three technical replicates. Error bars show standard deviation from the mean. (a) mcrA gene copies $\mathrm{ng}^{-1}$ DNA. (b) $m c r A$ gene copies $\mathrm{g}^{-1}$ pellet of centrifuged biomass with the supernatant removed. Note that the $y$ axis numeration is different between $a$ and $b$.

\section{SMA assays}

SMA assays were used to compare the biomass samples' maximum specific ability to produce methane given a particular substrate (Table 2) (Coates et al. 1996, 2005). Biomass sample CB had the highest SMA values for all three substrates tested (Table 2 ), biomass $\mathrm{KI}$ had the second highest activity against propionate and acetate, followed by biomass CF. However, biomasses MSS, MBR and JBS had higher activities against $\mathrm{H}_{2}: \mathrm{CO}_{2}$ than $\mathrm{KI}$ and $\mathrm{CF}$.

Table 2. Anaerobic waste treatment systems from which biomass was collected and their specific methanogenic activity (SMA) assay results

\begin{tabular}{|c|c|c|c|c|c|c|c|}
\hline Digester & Substrate & $\begin{array}{l}\text { SMA against } \\
\text { calcium } \\
\text { propionate }\end{array}$ & & $\begin{array}{l}\text { SMA } \\
\text { against } \\
\text { calcium } \\
\text { acetate }\end{array}$ & & $\begin{array}{l}\mathrm{SMA} \\
\text { against } \\
\mathrm{H}_{2}: \mathrm{CO}_{2}\end{array}$ & \\
\hline & & $\begin{array}{l}\text { (in } \mathrm{ml} \\
\mathrm{CH}_{4} \mathrm{~g}^{-1} \mathrm{VSS}^{-h} \text { ) }\end{array}$ & & & & & \\
\hline & & Average & Cv (\%)a & Average & Cv (\%) & Average & $\begin{array}{l}\mathrm{Cv} \\
(\%)\end{array}$ \\
\hline $\mathrm{CB}$ & Brewery waste & $14 \cdot 9$ & $6 \cdot 7$ & $21 \cdot 7$ & $2 \cdot 5$ & $31 \cdot 4$ & 0.0 \\
\hline $\mathrm{KI}$ & Milk-derived food additive waste & $3 \cdot 6$ & $6 \cdot 3$ & $11 \cdot 0$ & $6 \cdot 3$ & $8 \cdot 8$ & $3 \cdot 7$ \\
\hline $\mathrm{CF}$ & Dairy cow manure waste & $1 \cdot 1$ & $97 \cdot 0$ & $10 \cdot 1$ & $9 \cdot 4$ & 8.6 & $16 \cdot 0$ \\
\hline JBS & Beef slaughter waste & $0 \cdot 8$ & $29 \cdot 6$ & $4 \cdot 7$ & $48 \cdot 5$ & $12 \cdot 1$ & 0.0 \\
\hline MBR & Municipal waste & $0 \cdot 0$ & $0 \cdot 0$ & $5 \cdot 6$ & $66 \cdot 3$ & $10 \cdot 2$ & $26 \cdot 0$ \\
\hline MSS & Municipal waste & $0 \cdot 0$ & $0 \cdot 0$ & $6 \cdot 6$ & $97 \cdot 4$ & $15 \cdot 0$ & $17 \cdot 0$ \\
\hline
\end{tabular}

${ }^{a} \mathrm{Cv}(\%)$ is the coefficient of variation for the triplicates from each sample.

\section{Methanogen abundance and methane production rates}

Digester biomass qPCR results normalized to $g$ of wet pellet correlated well with corresponding SMA against $\mathrm{H}_{2}: \mathrm{CO}_{2}\left(R^{2}=0.67, P=0.046\right.$; Fig. 3a) and propionate $\left(R^{2}=0.70, P=0.038\right.$; Fig. 3b) but not with acetate $\left(R^{2}=0.49, P=0.12\right.$; Fig. $\left.3 c\right)$. These data obtained from SMA assays and qPCR performed on fullscale digester samples confirmed findings from a previous study that demonstrated a relationship between methane production rates and methanogen abundance in hydrogen enrichment cultures (Morris et al. 2014), although the correlation in this study was not as strong as found in the previous 
study. This finding is likely due to the nature of the biomass from the laboratory maintained enrichment cultures when compared to the industrial and municipal biomass.
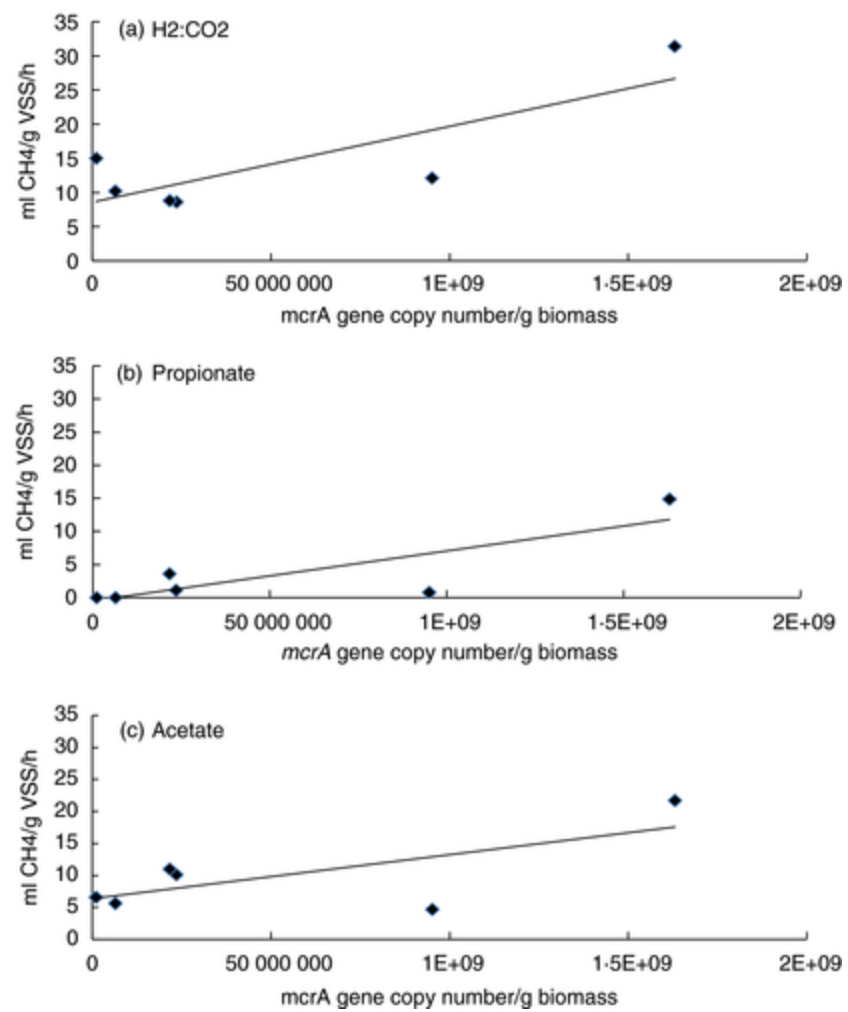

Figure 3. Correlation between specific methanogenic activity (SMA) assays and mcrA gene copy number per unit biomass from the six industrial and municipal digesters sampled. (a) SMA and $\mathrm{H}_{2}: \mathrm{CO}_{2}$. (b) SMA and propionate. (c) SMA and acetate.

The association between SMA against acetate in this study was not significant (Fig. 3c). This latter finding likely resulted from the fact that several groups of micro-organisms in digesters, in addition to acetoclastic methanogens, are able to utilize acetate, and that the relative abundance of these organisms could vary among the biomass samples tested.

The relationship between SMA and mcrA copy number was not dependent on the structure of a particular methanogen community or its composition (Fig. 1). This agreed with the results of the previous study which compared clone libraries to SMA values (Morris et al. 2014).

Taken together, the results of this study support the hypothesis that $m c r A$ copy number can be used to monitor and compare methanogen communities in some anaerobic digesters. Useful methods of monitoring systems must be sensitive and fast (Castellano et al. 2007; Molina et al. 2009). The ability of this methodology to produce results within a day that correlate well with SMA assays (which may take days to weeks to complete) satisfies both of these criteria, suggesting that quantifying methanogens may be a very useful technique for comparing biomass from different sources.

Although methanogenesis is often proposed to be the rate-limiting step in anaerobic digestion, the actual metabolic process that limits the rate of methane production may depend upon substrate composition (Liu and Whitman 2008). While monitoring micro-organisms at all trophic levels of the 
anaerobic food chain could provide valuable diagnostic information, this study shows a direct link between methanogen abundance and methane production rates in certain situations.

\section{Materials and methods}

\section{Sample collection}

Anaerobic biomass was collected from six industrial/mu-nicipal full-scale anaerobic systems that varied in substrate in the state of Wisconsin, USA (Table 1). Biomass samples CB and JBS were taken from an upflow anaerobic sludge blanket reactor and an anaerobic contact process, respectively, whereas the remaining biomass samples were from continuously-stirred tank reactors with no recycle. Biomass samples were collected in DNase-free centrifuge bottles, placed on dry ice for transport, and then stored at $-80^{\circ} \mathrm{C}$ until processing $(24-48 \mathrm{~h})$.

SMA assays

Methanogenic activity assays were conducted in triplicate under anaerobic conditions in 160-ml serum bottles with $25 \mathrm{ml}\left(<3 \mathrm{~g}\right.$ VSS, $\left.\mathrm{I}^{-1}\right)$ of biomass. The VSS concentration was determined according to Standard Methods (American Public Health Association et al. 1998) at the beginning and the end of activity tests and the average of the two values was employed for specific activity calculations. SMA for $\mathrm{H}_{2}$ : $\mathrm{CO}_{2}$ was determined by the method of Coates et al. (1996). Serum bottles were sparged with gas ( $4: 1 \mathrm{v} / \mathrm{v} \mathrm{H}_{2}: \mathrm{CO}_{2}$ ) and sealed with solid Balch-type butyl rubber stoppers. Immediately thereafter, $100 \mathrm{ml}$ of the $\mathrm{H}_{2}: \mathrm{CO}_{2}$ gas blend at ambient pressure and temperature was injected through the stopper using a syringe and a needle. Acetate and propionate SMAs were determined as described by Sorensen and Ahring (1993). Assays were supplied with $3 \mathrm{~g} \mathrm{l}^{-1}$ propionate or $10 \mathrm{gl}^{-1}$ acetate, each as the calcium salt, whereas the control assays were not supplied with substrate (Sorenson and Ahring 1993; Zitomer et al. 2008). All the propionate and acetate assays were then sparged with gas $\left(7: 3 \mathrm{v} / \mathrm{v} \mathrm{N}_{2}: \mathrm{CO}_{2}\right)$ to establish anaerobic conditions and sealed as stated above. Immediately after the addition of substrate to the test assays, all bottles were incubated at $35^{\circ} \mathrm{C}$ and shaken at $150 \mathrm{rev} \mathrm{min}^{-1}$. Bottle head-space volume was measured at ambient pressure (approx. $1 \mathrm{~atm}$ ) for 30 days by inserting the needle of a glass syringe with wetted barrel. The syringe content was re-injected into the serum bottle after volume measurement. Headspace methane content was analysed by gas chromatography (Agilent Technologies, Santa Clara, CA). Methane produced by the control assays accounted for endogenous decay, and was subtracted from methane produced by the test assays. Finally, maximum methane production rate $\left(\mathrm{ml} \mathrm{CH}_{4} \mathrm{~g}^{-1} \mathrm{VSS}-\mathrm{h}^{-1}\right)$ was determined as described elsewhere (Owen et al. 1979).

\section{DNA extraction}

Frozen biomass samples were thawed at room temperature. All samples were centrifuged at $10000 \mathrm{~g}$ for $10 \mathrm{~min}$ at $4^{\circ} \mathrm{C}$ (Avanti J-25, Beckman Coulter, Brea, CA). The supernatant was discarded, and DNA was extracted from the pellet using a combination of treatments from the RNA PowerSoil $^{\text {TM }}$ Total RNA Isolation Kit and DNA Elution Accessory Kit (MOBIO, Carlsbad, CA) according to manufacturer's instructions. DNA was then purified using the PowerClean ${ }^{\text {TM }}$ DNA Clean-up Kit (MOBIO). DNA integrity was examined by using a $1.5 \%(\mathrm{w} / \mathrm{v}$, Tris-acetate-EDTA buffer, Sambrook and Russell 2001) agarose gel. DNA concentration of purified extracts was determined spectrophotometrically (Nanodrop ND-1000, Thermo-Scientific, Wilmington, DE). 


\section{Quantitative PCR (qPCR)}

qPCR was performed according to the recommendations by Smith et al. (2006) and Smith and Osborn (2009) except for the standard curve, and according to MIQE guidelines (Bustin et al. 2009) which were applicable to environmental samples. qPCR standards were created using pooled mcrA DNA clones from anaerobic biomass samples as described previously (Morris et al. 2014). Quantification was performed using the primers designed by Luton et al. (2002): mcrF 5'-

GGTGGTGTMGGATTCACACARTAYGCWACAGC-3' and mcrR 5'-TTCATTGCRTAGTTWGGRTAGTT-3', as described previously (Vianna et al. 2006; Goffredi et al. 2008; Freitag and Prosser 2009; Freitag et al. 2010; Morris et al. 2014). The final qPCR mix per $25 \mu$ reaction was as follows: $1 \times$ $\mathrm{iQ}^{\mathrm{TM}} \mathrm{SYBR}^{\oplus}$-Green Supermix reaction buffer containing dNTPs, iTaq DNA polymerase and $3 \mathrm{mmol} \mathrm{I}^{-1} \mathrm{MgCl}_{2}$ (Bio-Rad, Hercules, CA); $750 \mathrm{nmol} \mathrm{I-1}$ mcrF and mcrR; and template DNA (0.3$1 \mathrm{ng}$ ). Each qPCR run included a no-template control. Quantification was performed on the $\mathrm{MyIQ}^{\mathrm{TM}}$ Single-Color Real-Time PCR Detection System (Bio-Rad) using the following programme: initial denaturation at $95^{\circ} \mathrm{C}(10 \mathrm{~min}), 35 \mathrm{cycles}$ of $95^{\circ} \mathrm{C}(30 \mathrm{~s}), 58.5^{\circ} \mathrm{C}(1 \mathrm{~min})$, and $72^{\circ} \mathrm{C}(3 \mathrm{~min})$, with a final extension of $7 \mathrm{~min}$ at $72^{\circ} \mathrm{C}$. The amplification programme was followed by a denaturation curve programme ( 80 cycles $10 \mathrm{~s}$ in length starting at $55^{\circ} \mathrm{C}$ and increasing in $0.5^{\circ} \mathrm{C}$ increments) to check for product specificity. Products from optimization runs were also examined for specificity using $1.5 \%$ agarose gels as described above. Starting quantity amounts and threshold cycle values were calculated using the Myiq ${ }^{\text {TM }}$ optical system software ver. 1.0 (Bio-Rad). Normalization 'per g of wet pellet' was also calculated using the $\mathrm{g}$ of biomass pellet after centrifugation and supernatant removal. Results were normalized to this parameter to account for differences in total solids among the biomass samples.

\section{Statistical analysis of qPCR and SMA results}

Linear correlation of the SMA data with the qPCR results normalized to ng of DNA and $g$ of biomass pellet, respectively, was performed using $R$ to calculate $R^{2}$ and $P$-values (Team 2008). Values were plotted with a trend line for visual analysis.

\section{Denaturing gradient gel electrophoresis}

DNA extracts from the full-scale digester biomass samples were PCR amplified with the mcrA specific primers described above with the exception that the forward primer was modified to include a GC clamp $\left(5^{\prime}-\right.$

CGCCCGCCGCGCCCCGCGCCCGTCCCGCCGCCCCCGCCCGGGTGGTGTMGGATTCACACARTAYGCWACAGC$3^{\prime}$ ) (Muyzer et al. 1993; Luton et al. 2002). The final component concentrations per $50 \mu \mathrm{I} P C R$ reaction were as follows: $100 \mathrm{nmol}^{-1}$ each primer, $0 \cdot 2 \mathrm{mmol} \mathrm{I}^{-1} \mathrm{dNTPs}, 1 \times$ Colorless GoTaq Reaction Buffer (Promega, Madison, WI) which contained $1.5 \mathrm{mmol} \mathrm{I}^{-1} \mathrm{MgCl}_{2}$ and $1.2 \mathrm{U}$ goTaq Polymerase (Promega). Template concentrations were approx. $100 \mathrm{ng}$ per reaction tube. The PCR conditions were as follows: initial denaturation at $95^{\circ} \mathrm{C}(5 \mathrm{~min}), 35$ cycles of $95^{\circ} \mathrm{C}(1 \mathrm{~min}), 58^{\circ} \mathrm{C}(1 \mathrm{~min})$, and $72^{\circ} \mathrm{C}(3 \mathrm{~min})$, with a final extension of $10 \mathrm{~min}$ at $72^{\circ} \mathrm{C}$. The programme included a slow ramp in temperature $\left(0 \cdot 1^{\circ} \mathrm{C} \mathrm{s}^{-1}\right)$ between the annealing and extension steps of the first five cycles of the protocol as recommended by Luton et al. (2002). The amplicon size was confirmed using a 1\% agarose gel as described above. Forty $\mu \mathrm{l}$ of PCR product was then used for DGGE in a $1 \mathrm{~mm}$ thick $8 \%$ polyacrylamide gel (37.5: 1 acrylamide to bis-acrylamide) with $40-70 \%$ denaturant gradient (urea and formamide). Electrophoresis at $100 \mathrm{~V}$ for $15 \mathrm{~h}$ was performed using the DCode ${ }^{\mathrm{TM}}$ Universal Mutation Detection System (Bio-Rad). The DGGE gel 
was stained with 1\% SYBR Gold Nucleic Acid Stain (Invitrogen, Grand Island, NY) for 30 min and visualized using the GelDoc ${ }^{\text {Tm }}$-It Imaging System (UVP, Upland, CA).

A dendogram representing the relationships between DGGE patterns of full-scale biomass samples was constructed using optical density data collected using labworks ${ }^{\mathrm{TM}}$ software (Lablogics, Inc., Mission Viejo, CA). Pearson's correlation coefficient ( $r$ ) was calculated using the densitometric data for each pair of samples. A distance matrix representing the relationships among the densitometric data was calculated using 1-r values. An unweighted pair group method with arithmetic mean (UPGMA) tree was plotted using the distance matrix and the PHYLIP software package (Felsenstein 2005).

\section{Acknowledgements}

We thank the owners and operators of the full-scale industrial and municipal anaerobic digesters that were sampled for providing us with biomass and operating information, and Mike Dollhopf of the Water Quality Center, Marquette University, for all his assistance during this investigation. Support for this work was provided by WE Energies and by Marquette University.

\section{Conflict of Interest}

There is no conflict of interest for any of the authors of this manuscript.

\section{References}

American Association for Public Health, American Water Works Association, and Water Environment Federation (1998) Standard Methods for the Examination of Water and Wastewater, 20th edn. Washington, DC: American Association for Public Health.

Bocher, B.T.W., Cherukuri, K., Maki, J.S., Johnson, M. and Zitomer, D.H. (2015) Relating methanogen community structure and anaerobic digester function. Water Res 70, 425- 435.

Bustin, S.A., Benes, V., Garson, J.A., Hellemans, J., Huggett, J., Kubista, M., Mueller, R., Nolan, T. et al. (2009) The MIQE guidelines: Minimum information for publication of quantitative real-time PCR experiments. Clin Chem 55, 611- 622.

Castellano, M., Ruiz-Filippi, G., González, W., Roca, E. and Lema, J.M. (2007) Selection of variables using factorial discriminant analysis for the state identification of an anaerobic UASB-UAF hybrid pilot plant, fed with winery effluents. Water Sci Technol 56, 139- 145.

Coates, J.D., Coughlan, M.F. and Colleran, E. (1996) Simple method for the measurement of the hydrogenotrophic methanogenic activity of anaerobic sludges. J Microbiol Methods 26, 237- 246.

Coates, J., Cole, K., Michaelidou, U., Patrick, J., McInerney, M. and Achenbach, L. (2005) Biological control of hog waste odor through stimulated microbial Fe(III) reduction. Appl Environ Microbiol 71, 4728- 4735.

Conrad, R. and Klose, M. (1999) Anaerobic conversion of carbon dioxide to methane, acetate and propionate on washed rice roots. FEMS Microbiol Ecol 30, 147- 155.

Felsenstein, J. (2005) PHYLIP (Phylogeny Inference Package) Version 3.6. Seattle, WA: Department of Genome Sciences, University of Washington.

Fernandez, A., Huang, S., Seston, S., Xing, J., Hickey, R., Criddle, C. and Tiedje, J. (1999) How stable is stable? Function versus community composition. Appl Environ Microbiol 65, 3697- 3704.

Freitag, T. and Prosser, J. (2009) Correlation of methane production and functional gene transcriptional activity in a peat soil. Appl Environ Microbiol 75, 6679-6687. 
Freitag, T.E., Toet, S., Ineson, P. and Prosser, J.I. (2010) Links between methane flux and transcriptional activities of methanogens and methane oxidizers in a blanket peat bog. FEMS Microbiol Ecol 73, 157- 165.

Goffredi, S., Wilpiszeski, R., Lee, R. and Orphan, V. (2008) Temporal evolution of methane cycling and phylogenetic diversity of archaea in sediments from a deep-sea whale-fall in Monterey Canyon, California. ISME J 2, 204- 220.

Juottonen, H., Tuittila, E., Juutinen, S., Fritze, H. and Yrjälä, K. (2008) Seasonality of rDNA- and rRNAderived archaeal communities and methanogenic potential in a boreal mire. ISME J 2, 1157- 1168 .

Kampmann, K., Ratering, S., Baumann, R., Schmidt, M., Zerr, W. and Schnell, S. (2012) Hydrogenotrophic methanogens dominate in biogas reactors fed with defined substrates. Syst Appl Microbiol 35, 404- 413.

Leclerc, M., Delgènes, J. and Godon, J. (2004) Diversity of the archaeal community in 44 anaerobic digesters as determined by single strand conformation polymorphism analysis and 16S rDNA sequencing. Environ Microbiol 6, 809-819.

Liu, Y. and Whitman, W. (2008) Metabolic, phylogenetic, and ecological diversity of the methanogenic archaea. Ann N Y Acad Sci 1125, 171- 189.

Luton, P., Wayne, J., Sharp, R. and Riley, P. (2002) The mcrA gene as an alternative to 16S rRNA in the phylogenetic analysis of methanogen populations in landfill. Microbiology 148, 3521- 3530.

McCarty, P.L. and Smith, D.P. (1986) Anaerobic wastewater treatment. Environ Sci Technol 20, 1200- 1206.

Molina, F., Castellano, M., García, C., Roca, E. and Lema, J.M. (2009) Selection of variables for on-line monitoring, diagnosis, and control of anaerobic digestion processes. Water Sci Technol 60, 615-622.

Morris, R., Schauer-Gimenez, A., Bhattad, U., Kearney, C., Struble, C.A., Zitomer, D. and Maki, J.S. (2014) Methyl coenzyme $M$ reductase (mcrA) gene abundance correlates with activity measurements of methanogenic $\mathrm{H}_{2} / \mathrm{CO}_{2}$-enriched anaerobic biomass. Microb Biotechnol 7, 77-84.

Muyzer, G., de Waal, E.C. and Uitterlinden, A.G. (1993) Profiling of complex microbial populations by denaturing gradient gel electrophoresis analysis of polymerase chain reaction-amplified genes coding for 16S rRNA. Appl Environ Microbiol 59, 695- 700.

Owen, W.F., Stuckey, D.C., Healy, J.B. Jr, Young, L.Y. and McCarty, P.L. (1979) Bioassay for monitoring biochemical methane potential and anaerobic toxicity. Water Res 13, 485- 492.

Rivière, D., Desvignes, V., Pelletier, E., Chaussonnerie, S., Guermazi, S., Weissenbach, J., Li, T., Camacho, P. et al. (2009) Towards the definition of a core of microorganisms involved in anaerobic digestion of sludge. ISME J 3, 700- 714.

Sambrook, J. and Russell, D.W. (2001) Molecular Cloning: A Laboratory Manual, vol. 1, 3rd edn. Cold Spring Harbor, NY: Cold Spring Harbor Press.

Schauer-Gimenez, A., Zitomer, D., Maki, J. and Struble, C. (2010) Bioaugmentation for improved recovery of anaerobic digesters after toxicant exposure. Water Res 44, 3555-3564.

Schink, B. (1997) Energetics of syntrophic cooperation in methanogenic degradation. Microbiol Mol Biol Rev 61, 262- 280.

Smith, C. and Osborn, A. (2009) Advantages and limitations of quantitative PCR (Q-PCR)-based approaches in microbial ecology. FEMS Microbiol Ecol 67, 6- 20. 
Smith, C., Nedwell, D., Dong, L. and Osborn, A. (2006) Evaluation of quantitative polymerase chain reaction-based approaches for determining gene copy and gene transcript numbers in environmental samples. Environ Microbiol 8, 804-815.

Sorensen, A.H. and Ahring, B. (1993) Measurements of the specific methanogenic activity of anaerobic digestor biomass. Appl Microbiol Biotechnol 40, 427-431.

Speece, R.E. (1996) Anaerobic Biotechnology for Industrial Wastewaters, 1st edn. Nashville, TN: Archaea Press.

Springer, E., Sachs, M., Woese, C. and Boone, D. (1995) Partial gene sequences for the A subunit of methyl-coenzyme $\mathrm{M}$ reductase $(\mathrm{mcrl})$ as a phylogenetic tool for the family Methanosarcinaceae. Int J Syst Bacteriol 45, 554- 559.

Steinberg, L. and Regan, J. (2009) mcrA-targeted real-time quantitative PCR method to examine methanogen communities. Appl Environ Microbiol 75, 4435- 4442.

Team, R.D.C. (2008) R: A Language and Environment for Statistical Computing. Vienna, Austria.: R Foundation for Statistical Computing, http://www.R-project.org/.

Vianna, M., Conrads, G., Gomes, B. and Horz, H. (2006) Identification and quantification of archaea involved in primary endodontic infections. J Clin Microbiol 44, 1274- 1282.

White, D. (2000) The Physiology and Biochemistry of Prokaryotes, 2nd edn. New York, NY: Oxford University Press.

Zeleke, J., Lu, S.L., Wang, J.G., Huang, J.X., Li, B., Ogram, A.V. and Quan, Z.X. (2013) Methyl coenzyme M reductase $A$ ( $m c r A$ ) gene-based investigation of methanogens in the mudflat sediments of Yangtze River estuary, China. Microb Ecol 66, 257- 267.

Zitomer, D.H., Johnson, C.C. and Speece, R.E. (2008) Metal stimulation and municipal digester thermophilic/mesophilic activity. J Environ Eng 134, 42- 47. 